\title{
De-Democratisation and Rising Inequality: The Underlying Cause of a Worrying Trend
}

\section{Dena Freeman}

Department of Anthropology and International Inequalities Institute, LSE

Working paper 12 May 2017 


\section{LSE International Inequalities Institute}

The International Inequalities Institute (III) based at the London School of Economics and Political Science (LSE) aims to be the world's leading centre for interdisciplinary research on inequalities and create real impact through policy solutions that tackle the issue. The Institute provides a genuinely interdisciplinary forum unlike any other, bringing together expertise from across the School and drawing on the thinking of experts from every continent across the globe to produce high quality research and innovation in the field of inequalities.

For further information on the work of the Institute, please contact the Institute Manager, Liza Ryan at e.ryan@lse.ac.uk.

International Inequalities Institute

The London School of Economics and Political Science

Houghton Street

London

WC2A $2 A E$

Email: Inequalities.institute@Ise.ac.uk

Web site: www.Ise.ac.uk/III

@LSEInequalities

f LSE Inequalities

(c) Dena Freeman. All rights reserved.

Short sections of text, not to exceed two paragraphs, may be quoted without explicit permission provided that full credit, including $\odot$ notice, is given to the source. 


\section{Abstract}

This paper is concerned with the question of why economic inequality has increased so dramatically in recent decades and what can be done about it. It suggests that the fundamental cause of the recent rise in economic inequality, underlying all the more proximate factors, is a major process of de-democratisation that has taken place since the 1970s, which has increased the political representation of capital while reducing that of labour. The paper pulls together a wide range of research from different disciplines in order to decisively show the ways in which economic governance has been de-democratised in this period. This analysis has important consequences with regard to policy attempts to reduce inequality and suggests that these must focus not on technical issues but on ways to strengthen democracy. And if the dynamics of dedemocratisation are fundamentally global, then solutions must also be global. These conclusions are in stark contrast with current academic and policy approaches which tend to focus on technical, rather than political, solutions, and which focus overwhelmingly at the national, rather than the global, level. This article thus calls for a major re-thinking of the causes of rising inequality and the policy changes needed to reduce it.

\section{Acknowledgements}

I would like to express my thanks to the LSE International Inequalities Institute for supporting this research through a grant from its Research Innovation Fund. I would also like to thank the many people who have commented on this paper, including Laura Bear, Catherine Boone, Deborah James, Mathias Koenig-Archibugi, Aaron Reeves and Paul Segal. An earlier version of this paper was presented at the International Inequalities Seminar in March 2017 and I am grateful also to the seminar participants for their insightful questions and feedback. The final views expressed here remain, of course, my own. 


\section{Introduction}

This paper is concerned with the question of why economic inequality has increased so dramatically in recent decades and what can be done about it. It suggests that the fundamental cause of the recent rise in economic inequality, underlying all of the more proximate factors, is a major process of de-democratisation that has taken place since the 1970s, which has increased the political representation of capital while reducing that of labour. The paper pulls together a wide range of research from different disciplines, which often do not speak to each other, in order to show clearly and decisively the ways in which economic governance has been radically dedemocratised in this period. This analysis has important consequences with regard to policy attempts to reduce inequality because in order to find solutions to a problem it is necessary to properly understand the root causes. And if the underlying cause of the rise in inequality is a diminishment of democracy then the solution must focus on ways to increase and strengthen democracy. And, as this paper further argues, if the dynamics of de-democratisation are fundamentally global, and play out in very many states in very similar ways, then solutions surely cannot be found at the national level alone but must also be sought at the global level. These conclusions are in stark contrast with current academic and policy approaches which tend to focus on technical, rather than political, solutions, and which focus overwhelmingly at the national, rather than the global, level. This article thus calls for a major re-thinking of the causes of rising inequality and the policy changes needed to reduce it.

The work of a number of economists has documented the huge increase in inequality that has taken place in many parts of the world since the 1970s. The U-shaped graphs of twentieth century income inequality in various countries produced by Thomas Piketty have quickly become famous. These graphs show a downward trend in income inequality from the start of the twentieth century until around 1970 and then a sharp upturn in inequality after that such that income inequality in 2010 is very similar to that in 1910. These trends are particularly marked in the Anglo-Saxon countries (US, UK, Australia and Canada) and in middle income emerging countries such as India, China. Argentina, Columbia, South Africa and Indonesia (Piketty 2014).

Understanding this recent rise in inequality has become a major concern in a number of academic fields and there are many competing theories offering explanations for this sudden change in inequality trends. For Piketty the reduction in inequality in the early and mid part of the twentieth century was just an anomaly brought about by two world wars and unusual political conditions. His book suggests that in the normal functioning of capitalism there is a continual increase in inequality because the rate of return on capital is greater than the rate of growth, which he sums up with the equation $r>g$. Scheve and Stasavage also argue that the post-war years were somewhat anomalous and develop the idea that the reduction in inequality in this period was due to the increased taxation and redistribution that governments were able to implement 
because of the changed social and moral calculus that came after the experience of mass warfare such that it became politically possible to tax the rich as a form of compensation because they generally did not fight in the war (Scheve \& Stasavage 2016). In both of these approaches it is assumed that rising inequality is the norm and that what needs to be explained is the period where inequality declined. The post1970 s rise in inequality, then, is just back to business as normal.

Other theories focus on technological and economic changes to explain the upturn in inequality in the post-1970s period. Popular views include the idea that the increase in inequality is largely a result of skill-biased technological change, such as computerisation, that has led to increased wages for skilled workers and decreased wages for the unskilled (Brune \& Garrett 2005:416). Others emphasize the huge increase in wages of CEOs and senior management in large corporations, the wealthiest $1 \%$, whose salary and benefit levels have skyrocketed in the past few decades (Atkinson \& Piketty 2010, Essletzzbicher 2015). And yet others have argued that various features of economic globalisation, such as increases in foreign direct investment and trade liberalisation, have led to increased inequalities, particularly in developing countries (Arbache et al 2004, Basu \& Guariglia 2007, Cornia \& Court 2001, Topalova 2004).

Whilst there is no doubt much truth in many of these theories, in this paper I argue that they all focus on proximate causes and that in so doing they all miss the fundamental cause that underlies all these other factors. Only by stepping back and looking at the big picture is it possible to more completely understand the drivers of rising inequality. And this is best done by exploring the broader political shifts in economic governance that have taken place in the past 50 years. This paper thus seeks to bring together a wide range of information and scholarship from a number of disciplines into one overall and accessible assessment in order to look critically at the changes in political representation, policy making and the functioning of democracy in the post-1970s era and to explore how these changes may be playing a part in the contemporary upswing of inequality.

In what follows I will first outline some of the theoretical discussions that have taken place regarding the relationship between democracy and inequality, and then briefly outline some of the major politico-economic changes that have taken place since the 1970s, namely neoliberalism, globalization and financialization. The main section then considers a number of ways that these changes have led to a transformation of democracy, and in particular the de-democratisation of economic policy making. The conclusion will consider the implications of these changes for inequality trends and for the type of action that must be taken if levels of inequality are to be reduced. 


\section{Democracy and Inequality - Theoretical and Empirical Perspectives}

There is a long history of the idea that increasing democracy will lead to a decrease in inequality. Nineteenth century elites resisted universal suffrage for this very reason, fearing that an impoverished majority would surely vote to appropriate their wealth and redistribute it more equally (Boix 2003, Dunn 2005). The 'redistributionist threat' of democracy was often expressed in terms of its incompatibility with private property. James Madison wrote in The Federalist, no 10 that "democracies have ever been spectacles of turbulence and contention; have ever been found incompatible with personal security and private property". Similarly Thomas Macaulay in his speech on the Chartists in 1842 expressed the view that universal suffrage would inevitably lead to "the end of property and thus of all civilisation" (cited in Przeworski 2006).

There are three basic mechanisms by which the reduction in inequality can be expected to occur. Firstly, as exemplified in social conflict theory and median voter models, it is suggested that democracy will reduce inequality because median voters will vote for redistribution by taxes and transfers (eg. Meltzer \& Richard 1981, Acemoglu \& Robinson 2000). Secondly, it is expected that since in democracies politicians have to compete for citizen support they will tend to provide more and better public services in order to win votes. Since the provision of public services will disproportionately benefit the poor, and also improve their ability to compete in the market place, this process drives the reduction of inequality (eg Saint-Paul \& Verdier 1993, Morgan \& Kelly 2013). Thirdly, democracies have features that empower workers and facilitate their involvement in the political process. Thus democracies allow freedom of association and collective bargaining and this can lead to increases in workers' wages, thus leading to a reduction in inequality (eg. Rodrik 1998).

However, against these theoretical expectations, attempts to show an empirical connection between democracy and inequality have been surprisingly inconclusive. Scholars using different data sets and different methodologies have not been able to come to an agreement about any general connection between democracy and inequality. Some scholars appear to find a correlation (eg. Chong 2001, Reuveny \& Li 2003), while others do not (eg. Ross 2006, Sirowy \& Inkeles 1990, Timmons 2010). These studies use quantitative methods to compare a large number of different contexts of democratization. The inconclusiveness of the results in these types of study has led some scholars to move to a more historical and qualitative approach, investigating particular historical episodes and undertaking an analysis of the specific political and economic dynamics at play (Capoccia \& Ziblat 2010, Gradstein \& Milanovic 2004).

From these studies a general pattern begins to emerge- the democratization of Europe in the nineteenth and early twentieth centuries did indeed lead to a significant 
reduction in economic inequality (Gradstein \& Milanovic 2004). However, democratization that took place in Eastern Europe and Latin America in the so-called 'third wave' of democratization in the 1980s and 90s (Huntingdon 1993) did not lead to a reduction in inequality and in fact in many cases led to an increase in inequality (Timmons 2010:735-6). While such a difference between these two different historical periods would explain why the regression analyses that combine many cases spread across different periods fail to find a correlation, it does not explain why these two very different patterns exist. Indeed, at first sight it appears rather paradoxical that the recent rise in inequality has taken place at the same time as a major spread of democracy worldwide.

Another body of literature has explored the connections between democracy and inequality in a different way. This literature has sought to explain the differing degrees of inequality that are exhibited in the long-existing European and American democracies. Some of these democracies have large welfare states, high levels of redistribution and relatively lower levels of inequality (such as those in continental Europe and Scandinavia), while others have much smaller welfare states, low levels of redistribution and correspondingly higher levels of inequality (such as the US and the UK). This suggests that there is no immediate or automatic connection between democracy and inequality and rather invites us to look more carefully at the political processes by which democratic politics shapes distribution and redistribution. Recent scholarship suggests that party political ideology, institutional features and electoral systems all significantly affect levels of economic inequality (Hibbs 1987, Iversen \& Soskice 2006, 2008, 2009). A major theme across much of this literature is that the redistributive differences in democracies are fundamentally due to the relative strengths of labour and capital as they are shaped by, and play out, in the political process (Korpi 1983, 2006; Huber \& Stephens 2001).

Despite their differences, all of these approaches share in common a theoretical framework that assumes a closed economy, such that issues of democracy and inequality can be explored by solely focusing on domestic actors and processes. While such an assumption may have been plausible during the post-war years of 'embedded liberalism' (Ruggie 1982), when capital controls limited the global flow of capital and states were able to set their own economic and social priorities while trading with other states at arm's length, it is clearly not plausible in the post-1970s period in which capital flows have become increasing global. In the context of economic and financial globalization it is necessary to develop a broader, more transnational, political economic analysis of actors, interests and strategies (Albertus \& Menaldo 2013). In other words, it is necessary to place debates about inequality and democracy in the context of globalisation (Freeman and Quinn 2012). 


\section{Global Changes in the post-1970s Era: Neoliberalism, Globalisation and Financialisation}

Neoliberal globalisation was initiated in the 1970s as a response to the slow down in economic growth, high inflation and the associated crisis of accumulation. In this crisis situation industrialists, investors and politicians all looked for new ways to stimulate growth.

It was in this context that the Keynesian paradigm which had dominated economic policy since the war came to be questioned and was finally replaced by neoliberalism, and particularly by the ideas of Hayek. A fundamental idea of neoliberalism is that 'the economy' is scientific and neutral and that the dynamics of growth are a technical matter that can be understood and modelled by calculations and formulae. In contrast to the socially embeddedness of Keynesianism in which efforts are made so that the economy serves the best interests of society, neoliberalism seeks to dis-embed the economy and have it function as a separate sphere. A key part of this is the idea that the 'economic' should to kept separate from the 'political'. Whilst this idea can be found in all capitalist theory and practice, the divide between the economic and the political is taken to new extremes in neoliberalism. Political and institutional matters are seen as factors which block the smooth running of 'the economy' and thus neoliberalism calls for a re-structuring of the state in order to increasingly free the economic from political constraints. This idea, as I will discuss more below, has been fundamental in the post 1970s restructuring of the state. And in the process, I will argue, it has led to the removal of large areas of economic policy making from democratic oversight (Cox 1992).

Hayek devoted considerable attention to the question of democracy and his relation to it was rather ambivalent. While he claimed to be in favour of democracy he also believed that it could lead to unhelpful interference in the workings of the economy. Thus for Hayek, democracy was only acceptable if it was 'limited'. By this he meant that there should be constitutional limitations such that most economic matters would be carefully bracketed out of democratic control. In particular, he argued that governments should not have the right to raise taxes for the purpose of redistribution, and he argued strongly against any notion of 'social justice'. In essence, his ideas about constitutional limits to democracy were effectively ways to ensure that the economic sphere would be carefully insulated from the demos and thus that democracy's redistributive threat would be neutralized (Hayek 1973, 1982, Pierson 1992). As we shall see, there have been many changes in this direction in the post1970 s period.

Another important aspect of neoliberal thought was that the economy was fundamentally universal and therefore should not be geographically limited in any way. Thus the globalisation of capital and its free movement worldwide was something that 
neoliberals actively sought to achieve. So it is important to remember that economic globalization, as it occurred in the post-1970s period, was not something that was purely driven by new technological innovations or by market forces. It was rather the outcome of specific policies that were designed and implemented by neoliberals who were part of new transnational economic policy networks which also developed in the early 1970s. These networks, consisting of official organisations such as the IMF and the World Bank, informal networks such as the G7 finance ministers and central bankers, and private transnational policy networks such as the World Economic Forum and the Trilateral Commission, are largely responsible for the transnational process of consensus formation about global economic policy and the form of economic globalisation that we have today (Baker 2008, Carroll \& Sapinksi 2010, Cox 1992, Miller 2010., Sklair 1997)

Space precludes a detailed discussion of the nature of post-1970s economic globalisation but the key elements that are worth noting here are (a) the globalisation of production and with it the increase in the number and importance of transnational companies (TNCs) and the shift to post-Fordist approaches; (b) the globalisation of capital and the deregulation of capital markets such that capital can move increasingly freely around the world; and (c) the massive increase in the size and importance of the financial sector, which is now much larger than the real economy, and which has led to a new context of 'financialisation' where financial motives, financial institutions, and financial elites have become increasingly important in the operation of the economy and its governing institutions (Epstein 2002, Palley 2008).

As we shall see, all of these processes, along with the increased globalisation of economic governance, have led to significant reductions in democracy. The next section seeks to explore how this has happened.

\section{Dynamics of De-democratisation}

A number of scholars have argued that globalization may sever the link between democracy and inequality, in particular by enabling asset-holders to move easily across borders in an effort to avoid redistribution, thereby preventing policymakers from taxing the rich in order to provide public services or transfers to the poor (Boix 2003, Dailami 2000, Freeman and Quinn 2012). While this is no doubt true, I think there is more going on than this. In order to understand the rise in inequality that has occurred in the post-1970s period of globalization it is necessary to look at the way that democracy itself has changed in this period. A basic tenet of democratic theory is that "the fate of a national community is largely in its own hands" (Held 1995:13). In the context of the neoliberal globalization of production and finance in the post-1970s period, this is becoming less and less the case.

In what follows I will argue that globalization has led to a process of economic dedemocratisation in line with Hayek's basic ideas. I am not claiming that there has been 
a complete erosion of democracy, or that states have been washed away by global capital. Rather I will try to show that decisions regarding the organisation and functioning of economic matters have become less subject to democratic influence. I will discuss three major ways that this has happened - by the direct removal of certain economics matters from political control, by increasing restrictions on the policy options available to policy-makers, and by transformations in the structure of the policy-making process itself.

\section{(1) Removing economic matters from direct political control}

The most obvious way that economic decision-making has become de-democratised has been the actual separation of major economic institutions and offices from political control. The most well-known example here is the increasing separation of central banks from political oversight. Since the mid-1990s the global economic policy consensus has been that central banks should be 'independent'. What this means, of course, is that central banks, and therefore monetary policy, should be insulated as much as possible from democratic reach. Central banks can be granted 'operational independence' or 'goal independence'. In the former the politicians set the policy goals but give the central bank autonomy to choose the vehicles by which to achieve these goals, while in the latter central banks also have the autonomy to set the goals of monetary policy (Hall 2008, Walsh 1995). Central banks are, however, not 'independent' when they are removed from democratic political control, but rather they must now respond to the demands of financial markets and those who operate them. Instead of being controlled by democratically elected politicians who can set monetary policy for social ends in the best interests of citizens, monetary policy is instead increasingly governed by the financial markets and the interests of financial capital (Epstein 2002:8,16).

Neoliberal discourse argues that monetary policy is a purely technical matter and thus best handled by experts and technocrats. However, as Epstein has argued, a political economy analysis highlights that 'the economy' is inherently 'political' and that monetary policy is in fact a contested terrain of class conflict as finance, industry and labour all have different interests and different preferences regarding the goal of that policy (Epstein 2002). Since the 1990s neoliberal theorists have put forth the argument that increasing the autonomy of central banks lowers inflation because central bankers, in contrast to democratically elected politicians, are less likely to be responsive to societal pressures that favour inflation, and can thus offer a credible, conservative and stable monetary policy that keeps inflation low without any adverse effects to the real economy (Rogoff 1985). However more recent research has shown that there is indeed an adverse effect to the real economy - in many cases, particularly in contexts of uncoordinated wage bargaining, the cost of this 'inflation targeting' is a rise in unemployment (Hall 1994, Hall \& Franzese 1998). Thus monetary policy involves a trade-off between the interests of capital (who favour low inflation as it protects against asset depreciation) and the interests of labour (who favour high 
employment). By insulating central bankers from democratic societal pressures, monetary policy ends up serving the interests of capital over those of labour (Epstein 2002).

Macroeconomic policy can also be redistributive. Governments that retain control of monetary policy and exchange rate controls can use macroeconomic policy to raise revenues to fund government services and transfers. They can, in effect, print money to fund government services. Thus, for example, many governments in Latin America such as Argentina, Bolivia, Chile and Venezuela have turned to the use of seigniorage to finance budget deficits oriented towards the poor. Countries that forsake this possibility, however, and opt for central bank independence and the ensuing policies of 'inflation targeting' are not able to redistribute in this way and their macroeconomic policies tend instead to favour the elites (Albertus \& Menaldo 2013). The point is that central bank policy is fundamentally political in that the outcomes of its policies have social consequences and affect different sectors of society differently. However the arrangement of central bank 'independence' means that the goals of monetary policy are effectively set by the interests of capital and that other interests are removed from the decision-making process (Epstein 2002).

Central banks are not the only economic institutions that are being bracketed off from political control. In the late 1990s there were calls to extend this model of 'independence' to other key policy areas, including even health and social welfare (Binder 1997). Whilst things have not (yet) progressed that far, a range of other economic and financial policy areas have become increasing 'independent' or 'autonomous'. Currency boards and sovereign debt management offices have largely followed the path of the central banks and been made increasingly 'independent' and thus are de-democratised in much the same way. This in turn means that in many countries' polices regarding exchange rates and sovereign debt payments are being taken out of democratic control and instead being made in the interests of capital and the financial markets.

In countries across the world there have been a raft of new constitutions and legal changes which act to legally, and permanently, separate the 'economic' from the 'political'. Whilst this is in no way a homogeneous process happening everywhere in the same way, it is a process that one way or another, and to differing degrees, is unfolding in very many countries. It is very common across Africa, where the World Bank and IMF have aggressively promoted the creation of autonomous enclaves within national bureaucracies, either in the form of increased 'autonomy' for Ministries of Finance or the placement of technocrats - often on the payroll of the IFIs - in key Ministries (Mkandawire 1999:127). And in Peru, to take just one example from the other side of the world, Teivainen has shown that after the transition to democracy and neoliberalism a new constitution was developed that defined various areas as 'economic' or 'financial' and then legally insulated these areas from parliamentary control. In this way the Peruvian Ministry of the Economy was given more power and 
at the same time it was increasingly shielded from democratic accountability, and in other ministries an increasing amount of policy-making was transferred to special teams which were insulated from public accountability (Teivainen 2002:22,133).

Another way in which this has happened is through the new-style trade agreements that have become widespread in the post-1970s era. As trade has increased new legal structures to protect property rights have been developed and written into international trade agreements. Thus many WTO trade agreements, the North Atlantic Free Trade Agreement (NAFTA) and other transnational trade agreements such as TRIPS and TRIMS, include provisions protecting the property rights of foreign capital over other rights. These rights are then insulated from present or future change as governments sign on their irreversibility. This means that future governments can be taken to private administrative tribunals and forced to pay for 'loss of expected profits' if they make laws or regulations for the public good that might impact on the future profitability of a corporation. In this way the political restructuring that is taking place today is being locked-in for the future, and thus also restricting the democratic ability of future generations (Gill 2002:56).

Stephen Gill has called this process the "new constitutionalism" (Gill 1998, 2002). It is clearly reminiscent of the type of constitutional limits that Hayek proposed. It serves to insulate certain important economic matters from democratic rule and popular accountability and instead places them in the hands of transnational capital and the financial markets. Thus in these fundamental areas of economic policy the representation of capital is increased while that of labour is decreased.

\section{(2) Restrictions in possible policy options}

While other areas of macroeconomic policy remain formally in the control of governments, a number of changes in the post-1970s global political and economic order have led to restrictions in the policy options that are available to domestic policy-makers. These restrictions have come about in two main ways - by the shifting of certain aspects of policy making up to the global level, and by the disciplining influence of global capital.

\section{(a) Restrictions in policy options due to global governance}

It is well known that there are serious democratic deficits at the global level. The IFIs are not democratic organisations and in most of them countries are represented according to the amount of money that they put into the organisation. Thus low and middle income countries are seriously underrepresented in discussions that take place in these forums. The G7, and even the larger G20, also only represent a small number of countries and yet seek to make decisions that affect the global economy. And the unofficial transnational policy networks such as the World Economic Forum and the Trilateral Commission are based on membership by invitation and as such mainly consist of political elites from the rich countries, directors and CEOs of TNCs, and 
people who are committed to neoliberal approaches. In short, capital is highly represented, while labour has very little voice at all, and rich countries are well represented while poorer countries have far less voice. At the global level economic governance is reminiscent of early nineteenth century European systems, where a small group of elites make decisions and the majority are disenfranchised.

And yet it is in these networks, what Gill has called the ' $G 7$ nexus', that broad economic policy consensus is formed that in turn shapes the discourse within which domestic governments can make economic policy. Whilst these global networks do not directly set policy themselves they define the discursive space in which domestic policies can be discussed. In this way non-democratic global policy processes significantly restrict and shape the policy options available to national level policy-makers.

It is worth noting that very little of serious economic significance is actually discussed at the UN. This is particularly noteworthy because the UN, despite its many shortcomings, is the most democratic institution that exists at the global level. Whilst it can in no way be considered fully democratic, at least in the General Assembly and in ECOSOC there is representation based on one country, one vote. So at the very least low and middle income countries, and leaders not necessarily committed to neoliberalism, have an equal voice in discussions. And it is through the UN that these voices have in the past expressed alternative views about how the global economy should be organised and governed. For contrary to neoliberal discourse there are of course numerous alternatives regarding how to govern a globalizing economy. One view was presented to the UN by the G77 countries in the early 1970s, for example, regarding their ideas for a New International Economic Order. Here is not the place to discuss the strengths and weaknesses of their proposals, although it is interesting to note that they included regulation of TNCs and forms of global redistribution to diminish inequality. What is important to note, I think, is that since then there has been no major discussion in any official global governance arena about alternative, nonneoliberal, forms of globalisation.

Instead, the rich countries have made continuous efforts to shift discussions about economic governance out of the UN to less democratic forums in order to maintain control of the outcomes. To give just one example, recent discussions about reforming elements of transnational tax policy, which as we shall see below is incredibly important for all countries, have taken place at the OECD with only rich countries represented, despite the calls of G77 countries to hold these discussions at the UN where they would also be represented.

What is important for our discussion here is that global policy processes are increasingly restricting national level policy making, and that these global policy processes are severely undemocratic. This, then, is one way that national level policy making is becoming de-democratised. 
(b) Restrictions in policy options due to the disciplining of global capital

Another way that policy options have been restricted at the domestic level is by the dynamics created by the global mobility of capital. Instead of regulating capital for the good of society, governments are now forced to compete with each other to attract capital to their countries. They are thus induced to choose policies favourable to investors and TNCs and to demonstrate that they promote a good 'business climate'. This has made it increasingly difficult for governments to pursue autonomous macroeconomic policy in a range of areas including exchange rates, interest rates, taxation and fiscal policy, as well as areas of social policy and labour policy (Held 1997:257). A whole 'economic surveillance' industry has developed with the IMF and the credit ratings agencies continually requesting economic data and information in order to analyse to what extent a particular country is 'good for business'.

The consequence of this is that governments have to increasingly set their economic policies to meet the wishes of these organisations which all follow a neoliberal approach which favours capital over other interests (Cox 1992, Gill 1998, Sassen 1996). In order to make themselves more attractive to capital countries are disciplined to lower corporate tax rates, reduce public spending and disempower unions so that labour can be made as cheap and as flexible as possible. This process of "disciplinary neoliberalism" (Gill 1998, 2002) has led to significant changes in all of these areas in very many countries in the post-1970s period. I will focus on changes in fiscal and social policy because these are particularly relevant for changing patterns of inequality. And since the dynamics are rather different in richer and poorer countries I will consider them separately.

\section{Rich Countries}

The combination of neoliberal ideology and global capital mobility has led to a major re-structuring of tax systems in most of the rich core countries. Average statutory corporate tax rates have fallen from around 50\% in 1980 to around $30 \%$ in 2005, and further since then. At the same time the tax base has been broadened by reducing investment allowances, depreciations, and other deductions (Ganghof \& Genschel 2008:59, Rixen 2011). This restructuring has left overall tax revenues largely unchanged and this led early scholars to believe that global tax competition was not in fact undermining fiscal sovereignty (Plumper, Troeger \& Winner 2009).

However more recent and nuanced studies have questioned this earlier optimism and have showed that the restructuring was itself driven by competitive pressures and that the outcomes of this restructuring are far from neutral. Cutting top corporate tax rates and broadening the tax base has meant that the tax burden has been shifted from TNCs to nationally organized small- and medium-sized companies, and from mobile to immobile economic factors. In this way tax on labour has increased, while tax on capital has fallen (Rixen 2011). Furthermore, since governments like to keep top 
personal income tax rates broadly in line with corporate tax rates (in order to stop tax avoidance by individuals incorporating themselves in order to pay lower taxes), the tax restructuring has also led to a decline in top rate personal income tax, further reducing the tax burdens of the wealthy. Thus the post-1970s tax restructuring has had important distributive consequences.

These policy changes have not been legitimately chosen by the states involved, but in most cases are rather forced upon them by competitive pressures in the globalising economy. In particular, governments are competing not only for foreign direct investment - real business activity - but also for 'paper profits' - profits that TNCs shift from one jurisdiction to another through all manner of, generally legal, accounting procedures. Several studies have shown that the mobility of these 'paper profits' is highly sensitive to tax rates and thus that it is competition for this type of capital that is driving down corporate tax rates (Rixen 2011). Furthermore, as some countries set very low corporate tax rates and offer high degrees of secrecy, these 'paper profits' are increasingly being shifted to tax havens and thus eliding the tax man in any country. Thus while states still possess the formal right to set tax policies they cannot effectively pursue certain desired policy goals. In other words, tax competition undermines the fiscal self-determination of states and significantly reduces their ability to effectively set the size of the budget and the extent of redistribution (Dietsch \& Rixen 2012).

Despite the relatively stable tax revenue in the post-1970s period, neoliberal reforms in social welfare policy have been common across the rich core countries (Castles 2004, Huber and Stephens 2001, Swank 2002). In the post-1970s periods firms and their interest associations have lobbied governments for rollbacks and efficiencyoriented reforms in national systems of social protection. They have argued that social programmes negatively affect profits, investment, and job creation and they have also used the threat of relocation to more favourable environments in order to put pressure on domestic policymakers. As I will discuss below, the ability of the private sector to influence government has significantly increased in the post-1970s period and thus changes have increasingly been made in the direction of their wishes.

Nonetheless welfare states have not simply collapsed in the process, as many predicted (Garrett and Lange1995, Geyer 1998. Scharpf 2000, Steinmo 2002). Democracy has not entirely withered away and since welfare state cuts are extremely unpopular with the electorate in most countries the process of rolling them back has been slow and difficult. But nonetheless, there has been a widespread process of change and retrenchment from the 1980s onwards. As Huber and Stephens (2001:123) summarize, "We find that roll-backs and 'restructurings' in welfare state programmes have been a universal phenomenon in the past two decades." Against earlier contentions that the welfare state was not changing (Pierson 1994), more recent studies have emphasisd the significant changes in social services, social policy administration, pensions, education, industrial relations and labour market policy that 
have taken place in European countries since the 1980s (Hemerijck 2013). Governments have periodically reduced income replacement rates, tightened eligibility rules and limited benefit indexation for core social insurance programmes. They have also employed greater targeting of benefits and encouraged the expansion of private insurance against labour market risks. Health and other social service programmes have increasingly been subject to budget caps, user co-payments, internal markets and other efficiency-oriented reforms. And in the heightened austerity of the post-2008 financial crisis era, where the public purse has run increasingly dry due to costly bank bail-outs and stimulus packages, welfare states are again facing more retrenchment as cuts are made to public services and transfers to the poor (Hemerijck 2013:9).

Nonetheless there has not (yet) been a wholescale dismantling of the welfare state. Most significant roll backs have occurred in countries whose political institutions act against pro-welfare state coalitions, such as the Anglo liberal political economies (Swank 2005:187). Welfare states in Scandinavia and continental Europe, where organised labour has more power and where electoral systems based on proportional representation more often lead to left wing governments, have proved much more resilient against the pressures of globalisation (Brady, Beckfield \& Zhao 2007, EspingAndersen 1996; Glatzer \& Rueschemeyer 2005, Steinmo 2002, Swank 2002). Thus democracy has not been completely eroded, but the economic pressures of globalisation have clearly placed restrictions on fiscal and social policy and driven them in a certain direction in most of the rich countries.

\section{Poorer Countries}

In poorer countries things have been much worse and in particular tax competition has proved a much bigger problem. While developed countries have been able to maintain the size of the budget by broadening the tax base and compromising on the extent of redistribution, developing countries have not been able to prevent revenue losses (Dietsch \& Rixen 2012). Since the 1990s their corporate tax revenues have been dramatically reduced as they have been forced to reduce corporate tax rates and offer tax holidays and other incentives in order to attract foreign investment, while not being able to broaden the tax base. Thus corporate tax revenues of developing countries declined from $2.9 \%$ of GDP in the early 1990 s to only $2.3 \%$ of GDP in the early 2000 s (Keen \& Simone 2004). Furthermore, transnational tax avoidance strategies of transnational companies (TNCs) have made it increasingly difficult for all countries to collect tax from them, and in particular developing countries whose tax administrations generally have lower capacities than those of the developed countries. Based on a range of data it is estimated that developing countries lose tax revenue equivalent to $20-30 \%$ of their actual tax income in this way (Mascagni, Moore \& McCluskey 2014:16). Christian Aid has suggested that the annual revenue loss of developing countries just from transfer pricing activities within TNCs is in the order of $\$ 160$ billion (Christian Aid 2008). For comparison, the total amount of money given in development aid per year from all countries and international organisations is about $\$ 130$ billion. 
Over the same period developing countries have also seen significant reductions in revenue from trade taxes as they have reduced tariffs in line with liberalisation policies (Baunsgaard \& Keen 2010). Combined this has led to significant shortfalls in the tax revenue collected by developing countries. While in OECD countries tax revenue is generally $30-40 \%$ of GDP, in developing countries it is only in the $10-20 \%$ range (Mascagni, Moore \& McCluskey 2014:10).

In this context of low tax revenue, developing country governments have been forced to either severely limit public spending or to take foreign loans to pay for it, or in many cases, a combination of the two. As a consequence public spending on infrastructure, service provision and welfare has plummeted in many countries since the 1980s (Rudra 2002, Wibbels 2006). At the same time, many countries have taken loans in order to ensure that at least a minimal public spending can continue. There has thus been a huge increase in the value of the sovereign debt of developing countries in this period.

It is well known that the ability of governments in developing countries to set their own macroeconomic policies has long been restricted by the conditionalities attached to loans from the IMF and the World Bank, and that these conditionalities have forced such countries to open their economies and implement neoliberal policies. With the increasing levels of sovereign debt in the post-1970s period these dynamics have increased and also transformed as governments have increasingly begun to take loans from private commercial banks.

A government's ability to attract credit on the capital markets, and the cost of this credit, is largely determined by its credit rating. This is a rating that private credit ratings agencies, notably Moody's and Standard and Poors (S\&P), give to a country after assessing the risk that it will pay back loans. Most importantly, if a country's credit rating goes down then the cost of interest on its debts will go up. Thus in the post1970s context of high indebtedness, developing country governments have been disciplined to enact policies that will please the ratings agencies. In this way private credit ratings agencies have become new sites of economic governance (Datz 2008, Sinclair 1994). Backed up by the prospect of loss of access to international credit markets and debilitating capital flight, the demands of the financial markets, filtered through the credit rating agencies, have seriously constrained the policy options available to many governments in low-and middle-income countries.

The types of policies that please credit ratings agencies are those that prioritise interest payments on debt over other forms of government spending. In this way governments have been increasingly disciplined to impose austerity policies and reduce government spending. Robert Cox has noted how the Mexican government had to abandon an agricultural reform designed to expand medium-sized farming for local consumption goods, which would have been beneficial to many of its citizens, and instead revert to large scale production of luxury export crops in order to earn 
dollars to service the country's debt (Cox 1992). Giselle Datz has argued that the Argentinian government's attempts to please the ratings agencies in the 1990s was the main driver leading to the subsequent collapse of the Argentinian economy, recession, a ballooning of its national debt and increased poverty and inequality (Datz 2008). Laura Bear has shown that as interest payments on government loans in India rose from $18 \%$ to $29 \%$ of GNP in the 1980 s and 90 s the requirement to make the interest payments came to dominate economic policy, leading to the implementation of neoliberal reforms and austerity policies. Certain agencies of the public sector became sites of centralized accumulation as the government sought to suck resources from them in order to pay off their external debt. Thus the Kolkata Port Authority, where Bear focused her study, was disciplined into cutting costs by reducing the workforce, shifting to more precarious forms of labour employment and renting out land to the private sector in an effort to channel money to the central government. Across the government funds that could have been spent on public services or social provision were instead directed to pay off the external loans and maintain their credit rating (Bear 2015).

Another change in the nature of sovereign debt in the post-1970s period is that it has been increasingly financialised. It is now packaged and repackaged in different forms of securities and traded on the bond market. In this form it is divided and traded amongst multiple investors, many trading in a short term and speculative frame. As the value of the debt thus rises and falls according to the swings of the bond market, governments now find it difficult to renegotiate these debts when necessary, thus making economic management much more difficult. As a result, argues Laura Bear, "economic policy becomes focused on appearing as a well-behaved debtor to an atomized market place of multiple bond holders and debt-instrument investors" (Bear 2015:12).

Thus in all these ways developing countries have further lost their ability to determine their own macroeconomic, fiscal and social policies.

\section{(3) Reductions in democratic accountability in the policy making process}

A third way that economic governance has been significantly de-democratised in the post-1970s period has been by changes in the structure of domestic policy making itself. Neoliberalism and globalisation have led to major re-structurings of the public sector in many core countries and this has led to significant reductions in the democratic accountability of the policy-making process.

In the late 1960s and early 1970s a number of observers began to argue that government had become 'overloaded' (Peters \& Pierre 2006). In response Margaret Thatcher and other politicians started to 'shed the load' by privatising state-run businesses and by increasingly sub-contracting and outsourcing government service provision to the private sector. Another aspect of the 'overloaded government' debate 
at the time was the argument that governments had become overloaded by the demands of their citizens. For example, the Trilateral Commission published a report in 1975 entitled The Crisis of Democracy which argued that as citizens had become more active and politically empowered they were demanding more services and more redistribution and this was posing a major challenge for governments (Crozier et al 1975). The diagnosis of the report was that there was an 'excess of democracy' and therefore that the solution was to limit democracy. While the report did not specify how this was to be achieved, it is perhaps no coincidence therefore that both of the major changes that took place in the public sector in the following years had the effect of taking many areas of policy-making out of democratic control.

Two new approaches were developed at this time - New Public Management Theory (NPM) and Governance theory. Both promoted their changes in the name of costcutting and efficiency. NPM can be seen as an extension of neoliberal theory as applied to the public sector. It calls for governments to embrace private sector management strategies. One aspect of this has been the call to devolve decisionmaking to smaller units, which can in turn compete against each other in order to reduce costs and improve efficiency. In effect it seeks to create internal markets within pubic administration (Osborne, \& Gaebler 1992). But in moving decision making to the lower level of agencies, political oversight is greatly diminished. Whilst NPM theorists are aware of this issue, they justify their approach by claiming that it is the outputs that confer legitimacy, rather than democratic processes of accountability (Benz \& Papadopoulos 2006:12). In their view citizens signal their choices as customers of services, rather than as citizens who vote. But in such a market-oriented view of representation citizens can choose between service providers, but they cannot vote for more or different services. And in the process the democratic accountability of elected representatives is severely reduced.

Governance theory in turn advocated a shift to a more decentralised form of policymaking whereby policy decisions would be made in collaboration with other stakeholders and non-state actors, particularly the private sector. The rationale for this change was that by engaging with a wider range of stakeholders the public sector would be able to mobilise private sector resources in pursuit of common goals. This has led to a shift from centralised decision-making by government to dispersed decision-making in policy networks in which government officials participate alongside representatives from TNCs, business associations and civil society groups (Peters \& Pierre 1998:226). In practice, this has led to a situation where policy decisions are increasingly made in forums that are not subject to democratic or parliamentary scrutiny. At the same time it has led to a situation in which the private sector has become directly involved in public decision-making (Benz \& Papadopoulos 2006:20).

While some have argued that this new form of policy-making is in fact more democratic than top-down government - because a wider range of stakeholders are involved, including also NGOs, consumer groups and other elements of civil society - it must 
be remembered that the resources available to large companies, TNCs and business associations to engage in these processes is far, far greater than that available to civil society groups, many of which are poorly funded and under-resourced. As one commentator noted, it is like lining up rowing boats against battle ships. Rather the shift to decision-making in multi-stakeholder policy networks has led to an increased representation of the private sector, and thus of capital, in the policy making process.

In the 1990s the move to de-politicise policy-making went even further and there were calls for policy to be made in 'non-majoritarian institutions' and for 'experts' to be increasingly involved in the policy process specifically because they were non-partisan and not accountable to the electorate (Mair 2006:27). At the same time there was an attempt to redefine democracy and to separate its constitutional and popular components, both in theory and in practice. Whilst much emphasis was given to the constitutional component, such as appropriate checks and balances across institutions and the role of courts and judges, the popular component, namely accountability to the people, was de-emphasised and rendered increasingly unimportant. Democracy was in effect de-democratised, or in Mair's terms, it was increasingly "stripped of its popular component", leading to "democracy without a demos" (Mair 2006:25)

In developing countries the situation is again much worse. Here government's role in policy-making has been reduced not by big business or by experts, but by the international financial organisations (IFIs) who often directly influence and shape the structure and functioning of the public sector. The World Bank and IMF routinely interfere in domestic policy making across the African continent, most notoriously through their Structural Adjustment Programmes from the 1980s onwards. Himbara and Sultan, for example, have argued that though the implementation of structural adjustment in Uganda "donor control has extended over the full range of policy mechanisms, feasibility research, project implementations and management of key elements of the Ugandan state"' (Himbara \& Sultan 1995: 90).

Anthropologist Gerhard Anders has shown how the involvement of these IFIs in domestic policy-making has only increased since then, particularly since the 1990s when matters of 'good governance' were included as part of IMF loan conditionality (Anders 2009). He documents how it was the IFls who set the agenda for civil service reform in Malawi, rather than the Malawian government. And he shows in great detail how Malawi's Poverty Reduction Strategy Paper - a government policy document was in effect written by World Bank and IMF staff, after several locally-produced versions were rejected by these organisations. He concludes that, in Malawi "national policy is rarely the product of the sovereign government or the national legislature" (Anders 2009: 47). Similar stories are found across the African continent, leading to what Thandika Mkandawire has called "choiceless democracies" - countries that are in theory democracies, but where the only possible policy option is that dictated by the IFIs (Mkandawire 1999). 


\section{Conclusion}

All of the changes discussed in this paper add up to an extremely significant transformation in the nature of policy making, political representative and democracy. The policy-making prerogative of states has been redistributed 'up' to the supranational level, 'down' to lower state levels and 'across' to the market (Yeates $2001: 11)$. And in contrast to the state, these new arenas of decision-making are largely insulated from democratic control. In this way economic issues have been depoliticised and increasingly removed from the arena of electoral politics. Furthermore, in each of the shifts that I have discussed the representation of capital in economic policy-making has been significantly increased, while that of labour has been correspondingly decreased. Thus I would contend that we not just seeing a transformation of democracy, as some scholars have argued, but rather that we are witnessing a process of de-democratisation and a shift towards elite rule.

And it is this process of de-democratisation, I argue, that is the fundamental underlying cause behind the recent increase in economic inequality that has taken place since the 1970s in so many countries of the world. I have tried to show how the trinity of neoliberalism, globalisation and financialisation have led to the situation where the 'economic' has been increasingly separated from the 'political'. I have also argued that this has not happened by accident, but that the 'limitation of democracy' - or what I call de-democratisation - is something that is fundamental in the thought of Hayek and other neoliberal thinkers. It is both desired and necessary in order to facilitate the further expansion of capitalism and to enable greater capital accumulation. The shift towards the increasing representation of capital in economic decision-making, and the decreasing representation of labour, has unsurprisingly led to economic policies being made increasingly in the interests of capital. In this way the class compromise of the post-war period has been undermined. These structural, political changes, I contend, are the fundamental reasons that underlie many of the more proximate causes of the upswing in inequality.

This analysis thus has major implications for how we should go about tackling the contemporary rise in inequality. It suggests that the problem, and therefore the solution, is fundamentally political, rather than technical. Therefore in order to bring about any significant and sustained process of reducing inequality it is imperative to find ways to bring about major political reform of the global system. First and foremost it is imperative to find ways to democratise economic policy making at both the national and the global level, and then to push for these changes to be implemented.

As such I would suggest that policy-oriented academics who are interested in devising ways to reduce inequality should start to focus on creating models for new kinds of democratic governance at both the national and global levels. This could involve, for example, bringing policy-making back from decentralised networks and into state 
structures at the national level, alongside the creation of state-like structures at the global level which would be able to regulate global capital for the good of society and through which policy alternatives, such as, for example, global social democracy, could be democratically debated - possibly in some sort of global parliament. Or it could involve devising ways to democratise de-centralised policy-making in national and global policy networks and in national and international financial organisations. There are, no doubt, many other possibilities and scholarship in this area is still extremely nascent. Whilst there is a small group of scholars working in the field of global democracy (eg. Archibugi, Held, Koenig-Archibugi, Marchetti) their work is currently not read or engaged with by scholars of inequality. Bringing these two groups of scholars together would be important and fruitful.

Devising models is one thing, getting them implemented is another. As this paper has argued, we are talking about a new chapter in the struggle between capital and labour. Thus I would suggest that there is an important role to be played by civil society and trade unions to make people aware of these processes of de-democratisation and to organise transnationally, not just around particular issues, but to push for institutional change and the wholesale democratisation of global governance. Because it is only by stopping the current process of de-democratisation and initiating a counter process of $(r e)$-democratisation that it may be possible to reverse the current inequality trends. 


\section{References}

Acemoglu, Daron and James Robinson. 2008. Persistence of Power, Elites and Institutions. American Economic Review, 98: 267-291.

Acemoglu, Daron and James Robinson. 2000. Why Did the West Extend the Franchise? Democracy, Inequality and the Growth in Historical Perspective. The Quarterly Journal of Economics, 115: 1167-1199.

Aidt, Toke and Raphael Franck. 2015. Democratization Under the Threat of Revolution: Evidence from the Great Reform Act of 1832. Economentrica, 83,2: 505-547.

Aidt, Toke and Peter Jensen. 2011. Workers of the World Unite! Franchise Extensions and the Threat of Revolution in Europe, 1820-1938. Cambridge Working Papers in Economics 1102, Faculty of Economics, University of Cambridge.

Albertus, Michael and Victor Menaldo. 2016. Capital in the Twenty First Century - in the Rest of the World. Annual Review of Political Science, 19:4.1-.418.

Albertus, Michael and Victor Menaldo. 2013. Macroeconomic Policy, Redistribution and Democracy https://ssrn.com/abstract=2317662

Anders, Gerhard. 2009. In the Shadow of Good Governance: An Ethnography of Civil Service Reform in Africa. Leiden: Brill.

Arbache, Jorge, Dickerson, Andy and Francis Green. 2004. Trade Liberalisation and Wages in Developing Countries. The Economic Journal, 114:F73-96.

Atkinson Anthony. 2015. Inequality: What Can Be Done? Cambridge: Harvard University Press.

Atkinson, Anthony and Thomas Piketty. (Eds). 2010. Top Incomes: A Global Perspective. Oxford: Oxford University Press.

Baker, Andrew. 2008. The Group of Seven. New Political Economy, 13,1: 103-115.

Basu, Parantap and lessandra Guariglia. 2007. Foreign Direct Investment, Inequality, and Growth. Journal of Macroeconomics, 29,4: 824-839.

Baunsgaard, Thomas and Michael Keen. 201-. Tax Revenue and (or?) Trade Liberalization. Journal of Public Economics, 94, 9: 563-577. 
Bear, Laura. 2015. Navigating Austerity: Currents of Debt along a South Asian River. Stanford: Stanford University Press.

Benz, Arthur and Yannis Papadopoulos. 2006. Governance and Democracy: Concepts and Key Issues. In Governance and Democracy: Comparing National, European and International Experiences, edited by Arthur Benz and Yannis Papadopoulos. London: Routledge.

Binder, Alan. 1997. Is Government too Political? Foreign Affairs, 76, 6: 115-126.

Boix, Carles. 2003. Democracy and Redistribution. Cambridge: Cambridge University Press.

Brady, David, Beckfield, Jason \& Wei Zhao. 2007. The Consequences of Economic Globalization for Affluent Democracies. Annual Review of Sociology, 33: 313334.

Brune, Nancy and Geoffrey Garrett. 2005. The Globalization Rorschach Test: International Economic Integration, Inequality and the Role of Government. Annual Review of Political Science, 8: 399-423.

Capoccia, Giovanni, and Daniel Ziblat. 2010. The Historical Turn in Democratization Studies: A New Research Agenda for Europe and Beyond. Comparative Political Studies, 43: 931-968.

Carroll, Willam and Jean Philippe Sapinski. 2010. The Global Corporate Elite and the Transnational Policy-Planning Network, 1996-2006 : A Structural Analysis. International Sociology, 25,4: 501-538.

Chong, Alberto. 2001. Inequality, Democracy, and Persistence: Is There a Political Kuznets Curve? Working Paper, Inter-American Development Bank, Research Department, No. 445. https://www.econstor.eu/bitstream/10419/88087/1/idb-wp 445.pdf

Christian Aid. 2008. Death and Taxes: The True Toll of Tax Dodging. http://www.christianaid.org.uk/getinvolved/christianaidweek/cawreport/index.a $\underline{\operatorname{spx}}$

Collier, Ruth. 1999. Paths Towards Democracy: The Working Class and Elites in Western Europe and South America. Cambridge: Cambridge University Press. 
Cornia, Giovanni and Julius Court. 2001. Inequality, Growth and Poverty in the Era of Liberalization and Globalization. Helsinki: UNU World Institute for Development Economics Research

Cox, Robert. 2002. Power and knowledge. In The Political Economy of a Plural World: Critical Reflections on Power, Morals and Civilization, edited by Robert W. Cox. London: Routledge. (pp76-95)

Cox, Robert. 1992. Global Perestroika. In New World Order? Socialist Register, edited by Ralph Miliband and Leo Panitch. London: Merlin.

Crozier, Michel, Huntingdon, Samuel and Joji Watanuki. 1975. The Crisis of Democracy: Report on the Governability of Democracies to the Trilateral Commission. New York: New York University Press.

Dailami, Mansoor. 2000. Financial Openness, Democracy, and Redistributive Policy. Washington DC: World Bank.

Datz, Giselle. 2004. Reframing Development and Accountability: The Influence of Sovereign Credit Ratings on Policy Making in Developing Countries. Third World Quarterly, 25, 2: 303-318.

Dietsch, Peter and Thomas Rixen. 2012. Tax Competition and Global Background Justice. The Journal of Political Philosophy, 22:150-177.

Dunn, John. 2005. Setting the People Free: The Story of Democracy. London: Atlantic Books.

Eichengreen, Barry and David Leblang. 2008. Democracy and Globalization. Economy and Politics, 20,3: 289-334.

Epstein, Gerald. 2002. Financialization, Rentier Interests and Central Bank Policy. Paper prepared for the PERI Conference on Financialization of the World Economy, University of Massachesetts, Amherst. https://www.peri.umass.edu/media/k2/attachments/fin Epstein.pdf

Esping-Andersen, G. (Ed). 1996. Welfare States in Transition: National Adaptations in Global Economies. London: Sage.

Essletzzbicher, Jurgen. 2015. The Top 1\% in US Metropolitan Areas. Applied Geography, 61,: 35-46. 
Franseze, Robert. 1999. Partially Independent Central Banks, Politically Responsive Governments, and Inflation. American Journal of Political Science, 43, 3:681706.

Freeman, John, and Dennis Quinn. 2012. The Economic Origins of Democracy Reconsidered. American Political Science Review, 106: 58-80.

Ganghof, Steffen and Philipp Genschel. 2008. Taxation and Democracy in the EU. Journal of European Public Policy, 15,1: 58-77.

Garrett, Geoffrey .1998. Partisan Politics in the Global Economy. Cambridge: Cambridge University Press.

Garrett, Geoffrey and Peter Lange. 1995. Internationalization, Institutions and Political Change. International Organization, 49, 4: 627-655.

Geyer, R. 1998. Globalization and the (Non) Defense of the Welfare State. West European Politics, 21, 3: 77-102.

Gill, Stephen. 2002. Constitutionalizing Inequality and the Clash of Globalizations. International Studies Review, 4, 2: 47-65.

Gill, Stephen. 1998. New Constitutionalism, Democratisation and Global Political Economy. Pacifica Review, 10,1: 23-38.

Gill, Stephen. 1986. Hegemony, Consensus and Trilateralism. Review of International Studies, 12:205-221.

Glatzer, M. and Rueschemeyer, D. (Eds). 2005. Globalization and the Future of the Welfare State. Pittsburgh: University of Pittsburgh Press.

Gradstein, Mark and Milanovic Branko. 2004. Does Liberte = Egalite? A Survey of the Empirical Links between Democracy and Inequality with some evidence on the Transition Economies. Journal of Economic Surveys, 18,4: 515-537.

Hall, Peter. 1994. Central Bank Independence and Coordinated Wage Bargaining: Their Interaction in Germany and Europe. German Politics and Society, 31: 123.

Hall, Peter and Robert Franzese. 1998. Mixed Signals: Central Bank Independence, Coordinated Wage Bargaining, and European Monetary Union. International Organization, 52, 3: 505-535. 
Hall, Peter and David Soskice. (Eds). 2001. Varieties of Capitalism: The Institutional Foundations of Comparative Advantage. Oxford: Oxford University Press.

Hall, Rodney. 2008. Central Banking as Global Governance: Constructing Financial Credibility. Cambridge: Cambridge University Press.

Hayek, FA. 1982. Law, Legislation and Liberty. London: Routledge.

Hayek, FA. 1973. Economic Freedom and Representative Government. London: The Institute of Economic Affairs. https://iea.org.uk/wp-content/uploads/2016/07/upldbook507.pdf

Held, David. 1997. Democracy and Globalization. Global Governance, 3:251-267.

Himbara, David and Dawood Sultan. 1995. Reconstructing the Ugandan State and Economy: The Challenge of an International Bantustan. Review of African Political Economy, 22, 63: 85-93.

Huber, Evelyne. and John.Stephens. 2001. Development and Crisis of the Welfare State. Chicago: University of Chicago Press.

Huntingdon, Samuel. 1993. The Third Wave: Democratization in the Late Twentieth Century. Oklahoma: University of Oklahoma Press.

Iversen, Torben and David Soskice. 2009. Distribution and Redistribution: The Shadow of the Nineteenth Century. World Politics, 61,3: 438-86.

Iversen, Torben and David Soskice. 2006. Electoral Institutions and the Politics of Coalitions: Why Some Democracies Redistribute More Than Others. American Political Science Review, 100, 2: 165-181.

Keen, Michael and Alejandro Simone. 2004. Is Tax Competition Harming Developing Countries more than Developed? Tax Notes International 34:1317-1325.

Korpi, Walter. 2006. Power Resources and Employer-Centered Approaches in Explanations of Welfare States and Varieties of Capitalism - Protagonists, Consenters, and Antagonists', World Politics, 58, 2: 167-206.

Korpi, Walter. 1983. The Democratic Class Struggle. London: Routledge.

Mair, Peter. 2006. Ruling the Void? The Hollowing of Western Democracy. New Left Review, 42: 25-51. 
Mascagni, Giulia, Moore, Mick and Rhiannon McCluskey. 2014. Tax Revenue Mobilisation in Developing Countries: Issues and Challenges. Brussels; European Parliament Policy Department.

http://www.ids.ac.uk/files/dmfile/TaxRevenueMobilisationinDevelopingCountri $\underline{\text { es.pdf }}$

Meltzer, Allan and Scott Richard. 1981. A Rational Theory of the Size of Government. Journal of Political Economy, 89: 914-27.

Miller, David. 2010. How Neoliberalism Got Where It Is: Elite Planning, Corporate Lobbying and the Release of the Free Market. In: The Rise and Fall of Neoliberalism: The Collapse of an Economic Order? edited by Kean Birch and Vlad Mykhnenko. London: Zed Books

Mishra, Ramesh. 1999. Globalization and the Welfare State. New York: Edward Elgar.

Mkandawire, Thandika. 1999. Crisis Management and the Making of 'Choiceless Democracies'. In State, Conflict and Democracy in Africa, edited by Joseph Richard. Boulder: Lynne Rienner Publishers. pp119-136.

Morgan, Jane and Nathan Kelly. 2013. Market Inequality and Redistribution in Latin America and the Caribbean. The Journal of Politics, 75, 3: 672-685.

Osborne, David and Ted Gaebler. 1992. Reinventing Government: How the Entrepreneurial Spirit is Transforming the Public Sector. New York: Addison Wesley.

Palley, Thomas. 2008. Financialisation: What it is and Why it Matters. IMK Working Paper, No. 04/2008. http://nbn-resolving.de/urn:nbn:de:101:1-20080818136

Peters, Guy and Jon Pierre. 2006. Governance, Accountability and Democratic Legitimacy. In Governance and Democracy: Comparing National, European and International Experiences, edited by Arthur Benz and Yannis Papadopoulos. London: Routledge.

Peters B. Guy and John Pierre. 1998. Governance Without Government? Rethinking Public Administration. Journal of Public Administration Research and Theory, 8,2: 223-243.

Pierson, Christopher. 1992. Democracy, Markets and Capital: Are there Necessary Economic Limits to Democracy? Political Studies, XL:83-98. 
Piketty, Thomas. 2014. Capital in the Twenty First Century. Cambridge: Harvard University Press. (trans: Arthur Goldhammer)

Plumper, Thomas, Troeger, Vera \& Hannes Winner. 2009. Why is There no Race to the Bottom in Capital Taxation? International Studies Quarterly, 53: 761-786.

Przeworski, Adam. 2008. Granted or conquered? A History of Suffrage Extensions. British Journal of Political Science, 39: 291-321.

Przeworski, Adam. 2006. Self-enforcing Democracy. In Oxford Handbook of Political Economy, edited by Donald Wittman and Barry Weingast. New York: Oxford University Press.

Reuveny, Rafael and Quan Li. 2003. Economic Openness, Democracy and Income Inequality: An Empirical Analysis. Comparative Political Studies, 36,5: 575601.

Rixen,Thomas . 2011. Tax Competition and inequality: The Case for Global Tax Governance. Global Governance: A Review of Multilateralism and International Institutions, 17, 4: 447-467.

Rodrik, Dani. 1998. Democracies Pay Higher Wages. Quarterly Journal of Economics, 114:707-38.

Rogoff, Kenneth. 1985. The Optimal Degree of Commitment to an Intermediate Monetary Target. Quarterly Journal of Economics, 100, 4: 1169-1189.

Ross, Michael. 2006. Is Democracy Good for the Poor? American Journal of Political Science, 50, 4: 860-874.

Rudra, Nita. 2002. Globalization and the Decline of the Welfare State in Less Developed Countries. International Organization, 56, 2: 411-445.

Ruggie, John. 1982. International Regimes, Transactions and Change: Embedded Liberalism in the Postwar Economic Order. International Organization, 36,2: 379-415.

Saint-Paul, Gilles and Thierry Verdier. 1993. Education, Democracy and Growth. Journal of Development Economics, 42:399-407.

Sassen, Saskia. 1996. Losing Control: Sovereignty in an Age of Globalization. New York: Columbia University Press. 
Scharpf, Fritz. 2000. The Viability of Advanced Welfare States in the International Economy: Vulnerabilities and Options. Journal of European Public Policy, 7,2: 190-228.

Scheve, Kenneth and David Stasavage. 2016. Taxing the Rich: A History of Fiscal Fairness in the United States and Europe. Princeton: Princeton University Press.

Sinclair, Timothy. 1994. Passing Judgment: Credit Rating Processes as Regulatory Mechanisms of Governance in the Emerging World Order. Review of International Political Economy, 1,1:133-159.

Sirowy, Larry and Alex Inkeles.1990. The Effects of Democracy on Economic Growth and Inequality: A Review. Studies in Comparative International Development, 25:126-157

Sklair, Leslie. 1997. Social Movements for Global Capitalism: The Transnational Capitalist Class in Action. Review of International Political Economy, 4,3: 514538

Steinmo, Sven. 2002. Globalization and Taxation: Challenges to the Swedish Welfare State. Comparative Political Studies, 35: 839-862.

Swank, Duane. 2005. Globalisation, Domestic Politics and Welfare State Retrenchment in Capitalist Democracies. Social Policy and Society, 4,2: 183195.

Swank, Duane. 2002. Global Capital, Political Institutions and Policy Change in Developed Welfare States. Cambridge: Cambridge University Press.

Timmons, Jeffrey. 2010. Does Democracy Reduce Economic Inequality? British Journal of Political Science, 40, 4: 741-757.

Topalova, Petia. 2004. Trade Liberalization, Poverty and Inequality: Evidence from Indian Districts. In Globalization and Poverty, edited by Ann Harrison. Chicago: University of Chicago Press.

Walsh, Carl. 1995. Central Bank Independence and the Short-Run Output-Inflation Trade-Off in the European Community. In Monetary and Fiscal Policy in an Integrated Europe, edited by Barry Eichengreen, Jeffry Frieden and Jurgen von Hagen. Berlin: Springer.

Yeates, Nicola. 2001. Globalization and Social Policy. London: Sage. 
Wibbels, Erik. 2006. Dependency Revisited: International Markets, Business Cycles, and Social Spending in the Developing World. International Organization, 60,2: 433-468. 